

\title{
The Challenge of Peace Building and Conflict Transformation: A Case Study of Northern Ireland
}

\author{
Neil Jarman \\ Queen's University, \\ Institute for the Study of Conflict Transformation and Social Justice
}

\begin{abstract}
This paper provides an overview of the transition from armed conflict to peace in Northern Ireland between 1994 and 2016. It discusses the main stages of the peace process and the main elements of the peace agreement in relation to the development of global thinking around peacebuilding as set out in the United Nations 1992 report Agenda for Peace and the 2000 Brahimi Report. The paper argues that while Northern Ireland is often highlighted as a positive example of peacebuilding, its example is not without limitations. Overall, the experience of the past twenty years emphasizes the importance of ensuring a broadly inclusive process and the need for a sustained commitment over a long period.
\end{abstract}

Key Words: Northern Ireland, peacebuilding, conflict transformation, inclusiveness, sustainability, United Nations.

\section{Introduction}

The ending of the armed conflict in Northern Ireland and Northern Ireland's ongoing transition to a more peaceful society has been widely regarded as one of the most successful examples of global peace building and conflict transformation. The conflict, which began in August 1969, formally ended with the signing of the Belfast/Good Friday Agreement in April 1998 by the British and Irish governments with the support of the main Northern Irish political parties. The peace process and the Agreement was one element of an important decade for global peace building, which began with the transformations in Eastern Europe and the 1989 collapse of the Soviet Bloc that ended the Cold War. This, in turn, led to new initiatives for and developments in ending conflict.

At the decade's beginning, the United Nations initiated a broad review of international approaches to conflict. This led to the elaboration of the concept of peace building in the 1992 report An Agenda for Peace by Secretary General Boutros Boutros-Ghali. The decade's end in 2000 saw the publication of the Brahimi Report on United Nations peace operations, as well as the passing of UN resolution 1325 on women, peace and security.

The decade also was marked by contrasting experiences in dealing with violent conflict. There was important progress in bringing to an end long-running conflicts in Lebanon, South Africa and Northern Ireland, as well as what has since proved to be misplaced optimism on 
progress on another major long-running conflict, the conflict between Israel and Palestine. Yet this apparent progress had a counterpoint - the failure of the international community to respond effectively to the violence in Yugoslavia and Rwanda.

Northern Ireland is widely highlighted as one of the most successful recent examples of global peacebuilding. In twenty years, it has been transformed from a place of persistent conflict to a stable democracy, albeit one that occasionally appears in the global media because of a crisis or violence. More frequently, Northern Ireland is presented as a model of how local participants, with the support and assistance of international actors and institutions, can transform a long-standing armed conflict into a viable, sustainable peace. Many state and nonstate actors from other conflict areas frequently visit Northern Ireland. In turn, Northern Irish politicians and peace builders are often invited to other conflict zones to explain what they have achieved and how they did it.

This is perfectly reasonable. In the early stages of the Northern Ireland peace process, people in Northern Ireland had sought inspiration, advice and assistance from other countries exiting conflict; in particular, they were inspired by South Africa's transition. Northern Ireland is also significant as one of the relatively few examples of armed conflicts in Europe in the second half of the twentieth century. While drawing exact parallels between different conflicts is never possible, some broad lessons can be learned and adapted to fit other contexts. Acknowledging successful examples of peace building is important. Yet, more important is understanding why building peace was possible, the key elements of peacebuilding, the limits of any conflict transformation process and the challenges that are always faced in trying to move any society away from using violence to achieve political ends.

This paper draws on the author's more than twenty years of work on the political transition and peace processes in Northern Ireland. This includes work at the grass roots and with civil society organizations, government departments, politicians, former combatants, faith leaders, young people, supporters of the peace and those who opposed or rejected the process. It has involved academic research, evaluation, documentation and policy development as well as advocacy, training delivery and practical activism. At the very least, this work highlights the length of time it can take to begin the process of transition after a violent conflict, the process's complexity and the diverse actors who may be involved. These factors are often overlooked when considering the conflict transformation process from afar.

The paper overviews the Northern Ireland peace process by outlining its various steps and stages, highlighting peace agreement's key elements and their implementation, and reflecting on the progress made and the challenges that remain. The paper begins by contextualizing the discussion of the Northern Ireland conflict within the framework of the broad models of peace building and conflict transformation that have been developed during recent decades by academics and by international bodies such as the United Nations. In particular, it reviews the key elements of peacebuilding that have been identified by the United Nations and considers how they affected Northern Ireland's transition. It also considers some of the international vision's gaps and limitations by drawing on a bottom-up and inside-out perspective in contrast to the United Nations' top-down view. 


\section{Concepts and Ideas in Peacebuilding}

The debates within the United Nations and the ideas in the Agenda for Peace and Brahimi Report were important international perspectives on ending conflict because they broadened understanding about international peacemaking interventions and highlighted the need for approaches for consolidating a sustainable peace. The Agenda for Peace introduced the term "post-conflict peace building" to the peacemaking and peacekeeping lexicon as a form of "sustained, co-operative work to deal with underlying social, cultural and humanitarian problems" that had to be addressed to provide a durable foundation for peace and preventing a recurrence of violent conflict. ${ }^{1}$ The Brahimi Report elaborated on this by identifying six key features of any peacebuilding strategy: (1) actively engaging with local parties and creating quick-impact projects designed to have a real impact on quality of life; (2) holding free and fair elections; (3) reforming policing and justice systems based on international standards; (4) establishing a culture of human rights in the new institutions; (5) disarming, demobilizing and reintegrating former combatants; and (6) developing a co-ordinated strategic framework for all aspects of peace building. ${ }^{2}$ UN Resolution 1325 expanded this approach by highlighting the need for gender perspectives in all aspects of post-conflict peace building, including "the need to support local women's peace initiatives and indigenous processes for conflict resolution [...] that involve women in all of the implementation mechanisms of the peace agreements." ${ }^{3}$ The two reports and the resolution were significant in highlighting the importance of developing a longer-term perspective on the transition from violent conflict to a sustainable peace and in recognizing that such transitions are often complex and uncertain processes.

Peace processes are often fragile and unstable. Too often the peace collapses when one or more parties resort to force because they believe that they have not sufficiently achieved their objectives or have obtained insufficient power or other benefits from peace. ${ }^{4}$ In part as well, a peace's fragility has resulted from the international community's failure to commit sufficient time, attention and resources to building peace, often hoping that securing agreement among the political elites would prove sufficient to end the violence. This approach to peace building may involve little more than a dialogue that results in a peace agreement among the local political elite, with their committing to reform the political and security institutions and agreeing to a process to disarm and reintegrate irregular armed groups. This will culminate in an election and the creation of a new government. Then, after a relatively short period, the process will be declared a success, and the international community will begin to shift its focus elsewhere. However, the situation in the supposed "post-conflict" society is often less stable

Boutros Boutros-Ghali, An Agenda for Peace (New York, United Nations, 1992), para. 57. Available at: http://www.un-documents.net/a47-277.htm. Accessed May 25, 2016.

2 Brahimi Report, Report of the Panel on United Nations Peace Operations (New York, United Nations, 200o), paras. 37-46. Available at: http://www.un.org/en/ga/search/view_doc.asp?symbol=A/55/305. Accessed May 25, 2016.

3 UN Resolution 1325, para. 8c. Available at: http://www.un.org/womenwatch/osagi/wps/\#resolution. Accessed May 25, 2016.

4 See Paul Collier, Wars, Guns and Votes: Democracy in Dangerous Places (London: Vintage Books, 2010). 
than hoped. And too often some form of violent conflict will recommence. If such violence is contained in a discrete area or remains at a low level, it may come to be seen as part of the "new normal." The situation may be recognized as not ideal, but it is may also be accepted as better than it might have been.

While the elements the UN reports outlines are undoubtedly important features in building a sustainable peace and have all been aspects of the political transition in Northern Ireland, they are rarely sufficient. Practical experience on the ground has highlighted additional factors that are important to creating a sustainable peace. These include grass roots, peacebuilding work as a complement to elite-level negotiations; adequate resources to support and sustain peace building; adequate investments of time; recognition of the importance of relationships, attitudes and social justice; and infrastructure, institutions and elections that ensure an embedded peace.

Johan Galtung has highlighted two contrasting forms of peace that he characterizes as a "negative peace" and a "positive peace." 5 Galtung argues that a negative peace exists where there is an absence of violence and a degree of safety and security for the civilian population, but the main issues that helped to ignite the conflict in the first place have not been addressed, thus leaving the society open to a resumption of violence. In contrast, he defines a positive peace as existing where the structural inequalities and injustices that ultimately led to the violence have been addressed, and thus a more sustainable peace is possible. A negative peace is something that may be achieved, or sometimes imposed, relatively quickly, but building a positive peace is a longer and more wide-ranging process, and it demands a more extensive commitment from a wider range of society's sectors.

Galtung's concepts overlap with other academic thinking about ending conflict and, in particular, the development and elaboration of such related concepts as conflict management, conflict resolution and conflict transformation. ${ }^{6}$ Conflict management usually refers to actions designed to limit, mitigate or contain violent conflict, while approaches to conflict resolution may focus on seeking accommodation and compromise between warring parties and on reaching an agreement to share power as a path out of violent conflict. Neither of these approaches will necessarily aim to address the deeper roots of the conflict. In contrast, models of conflict transformation aspire to a more wide-ranging transition, including transforming personal and collective relationships, building deeper understandings and recognition of difference, as well as addressing the often deep-rooted structural factors and inequalities that generate tensions that can lead to violence.

Conflict management and conflict resolution are thus more limited and pragmatic responses to violence. They aim to end a conflict and establish a degree of stability in a relatively short time, whereas conflict transformation is a more radical and challenging approach that looks to a longer-term response to build a more equitable society based on social justice and human rights. And whereas approaches to conflict resolution may be top-down and elite-led processes, models of conflict transformation emphasize the need for a broadly inclusive process 
that involves the political elite and grass roots activists and highlights the roles of "middle level" leaders who help to link and connect the elite and the grass roots. ${ }^{7}$ In such an approach, peace has to be built from the bottom-up as much as from the top-down, and those at the grass roots are important actors in the process rather than simply being reliant on the trickle-down benefits of high-level deals.

In reality, building peace and transforming a conflict is always a process rather than an event. It will be messy, complex and uncertain. It will rarely be a simple trajectory but rather will oscillate between periods of stable peace and periods of tension and disorder and even a return to violence. ${ }^{8}$ The transition process will be impacted by such factors as the nature, scale and duration of the conflict; the nature of the peace, whether it is a victor's peace, involves territorial division or a military stalemate and compromise ${ }^{9}$; the nature and scale of any involvement by other states or international bodies; as well as the expectations and relative power of the different actors. At times the future will look positive, at other times less so; opportunities may appear but then disappear again; external factors such as relations in or with neighboring peoples, regions or countries or elements of the global economy may impact in significant, but unforeseen, ways; internal dynamics and power relations will almost certainly change over the course of a peace process; mistakes will be made and hindsight will serve as a source of reflection. Establishing a stable peace may also take much longer than expected, which will impact on the level of resources and support available to different actors. The duration and trajectory of a transition may thus impact on whether one aspires for a more pragmatic resolution or a more idealized transformation of the wider social, political, institutional and economic context.

The next section briefly outlines the Northern Ireland conflict's background. It highlights some of the key stages in the attempts to build peace over the course of the conflict and offers an overview of the peace process main elements and the peacebuilding overarching context. It is followed by a discussion of the peace process key stages between 1994 and 2015. It outlines some of the successes that have been achieved and the challenges that remain to be addressed. This later section also contextualizes the peace process in Northern Ireland in relation to the academic ideas of peacebuilding and conflict transformation that have been outlined above.

\section{From Conflict to Peace: The Northern Ireland Context}

Northern Ireland was established in 1921 when Ireland was partitioned by the British government following a sometimes-violent campaign for independence. Most of Ireland became an independent state, while the north-eastern part of the island remained a part of the United Kingdom. Northern Ireland has always been a divided society, with the majority Protestant population supporting the union with Britain, while the minority Catholic population supported

7 John-Paul Lederach, Building Peace: Sustainable Reconciliation in Divided Societies (Washington: United States Institute of Peace, 1997). and Youth (Notre Dame, Ind.: University of Notre Dame Press, 2006) and John Darby, ed., Violence and Reconstruction (Notre Dame, Ind.: University of Notre Dame Press, 2006). 
a united Irish Republic.. ${ }^{10}$ In the 196os, a civil rights campaign began to demand an end to discrimination against members of the minority Catholic community, drawing inspiration from the US civil rights movement. This was opposed by members of the majority Protestant community who were backed by the local police, the Royal Ulster Constabulary. Increasing tensions in the late 196os led to serious inter-communal rioting, and, in 1969, the British Army was deployed by the government in London to restore order. However, this led to a further polarization of positions. The demand for equality soon became a demand for a united Ireland, while street protests escalated into armed conflict. This three-sided conflict, which involved state forces (the British Army and the Royal Ulster Constabulary) and paramilitary groups from the Nationalist community (Irish Republican Army and Irish National Liberation Army) and the Unionist community (Ulster Volunteer Force and Ulster Defence Association) lasted until 1994 when the paramilitary groups declared ceasefires.

Throughout the conflict there were attempts to reach a political solution to the violence, which, while unsuccessful at the time, did serve as the foundation to the subsequent peace process. The British government introduced legal reforms to address the issues of discrimination in the early 1970s, but by then the armed conflict was raging. A political agreement in 1973 established a power-sharing government, but this collapsed after opposition from sections of the Protestant community. In the 1980s dialogue between the British and Irish governments led to the 1985 Anglo-Irish Agreement, which gave the Irish government an advisory role in relation to the government of Northern Ireland for the first time. The British government also maintained informal channels of communication with the IRA throughout the conflict, but these did not really bear fruit until the 199os, by which time there was an element of war fatigue, with both the British Army and the IRA realizing that they could not win a purely military conflict. Alongside these processes, Sinn Féin, the political wing of the IRA, began in 1981 to develop a more overt political strategy, which was designed to run in parallel with the IRA's armed campaign. This, in turn, led to more structured talks both with the constitutional Nationalist parties and with the British government through the informal "back channels." These paved the way for the IRA to declare a ceasefire on 31 August 1994. The Loyalist paramilitary groups followed suit six weeks later and the formal public peace process began.

The Northern Ireland peace process per se can be broken down into three broad phases. The first phase, which involved elite-level political negotiations and a diverse array of grass roots work, ran from the ceasefires in 1994 until support was secured for the peace agreement and the elections held in June 1998. The second phase, which lasted until May 2007, was marked by a period of instability in the devolved government and by a flourishing of grass

The terms Protestant and Catholic are widely used as descriptors of the two main communities in Northern Ireland and while they imply a religious underpinning to the conflict the two terms should better be considered as ethno-national communities. The conflict is over the constitutional status of Northern Ireland within either the United Kingdom, or the Republic of Ireland. The Protestant community largely identifies as British and favors remaining within the United Kingdom, politically they are Unionists, while hard-line more radical sections are referred to as Loyalists. The Catholic community largely identifies as Irish and favors a unified Irish state, politically they are Nationalists, while hard-line more radical sections are referred to as Republicans. 
roots peacebuilding activities. The third phase began with the restoration of a devolved powersharing government in May 2007. Overall, peace building in Northern Ireland has been a broadly inclusive multi-party, multi-level process that has involved the local political parties, the British and Irish governments and local civil society. It has also drawn on the support of the American government at key stages, involved key international figures to assist in various aspects, and benefited from the financial support of the European Union and various American and international donors.

Whilst the peace has resulted in a massive decline armed violence, deaths and bombings, it has also been marked by sustained periods of street protests and rioting that have threatened to collapse the process. Thus, while the declarations of ceasefire initiated a shift away from armed conflict, the early stages of the transition were marked by sustained mistrust and suspicions between the two main communities both at the political and the grass roots levels. To reverse the Clausewitzian aphorism, in Northern Ireland "peace has been a continuation of war by other means." This was in large part due to the form that the peace process took. John Brewer has argued that conflicts come to an end in one of three ways: by the victory of one of the parties (what he calls "conquest peace"); through the geographical division and the redrawing of national boundaries (cartography); or through compromise and negotiation involving the main conflicting parties. ${ }^{11}$

The peace in Northern Ireland has followed the third of these. Unlike in South Africa, there was no ultimate victor who could dictate the terms of the peace. Division had been tried in Ireland in 1921, but this had only served as a temporary remedy. Thus, the peace process has pursued dialogue and negotiation in search of a compromise that could provide the foundations for a sustainable peace. And while the peace has been pursued as an inclusive process (at least for those who profess to be committed to peaceful means), it has also been multi-layered, involving two national governments, numerous political parties, representatives of several armed groups plus sections of civil society. It has also included parties and groups with differing demands, expectations and commitments to the ongoing process. So while the armed groups considered their declarations of ceasefire as sufficient ground for inclusion in talks, other parties, particularly the Unionist parties, demanded initially at least more evidence of a commitment to peace, and they refused to engage in dialogue with the Sinn Féin while the IRA retained its weapons. The nature of the beginnings of the transition highlighted the importance of the process being broad, inclusive and involving relationship- and trust-building at the grass roots level as well as focusing on negotiations toward an agreement.

\section{Phase One: Ceasefires to Agreement}

The first phase of the peace process was focused on the political negotiations between the two governments and the local political parties, primarily to reach an agreement over the form and content of any future political institutions in Northern Ireland. This process lasted for more than three and a half years and was marked, as noted above, by persistent and serious inter-communal tensions, disputes over the involvement of Sinn Féin in the discussions and 
the breaking - and then resumption — of the IRA ceasefire. One of the distinctive features of this stage of the process was the elections in May 1996 to the Northern Ireland Forum for Political Dialogue, a body that was established to legitimize political participation in the peace negotiations. The ten parties with the largest number of votes in the elections were entitled to seats in the Forum and ultimately the right to participate in negotiating the agreement. The process was specifically designed as a means of enabling two small parties associated with the Loyalist paramilitary groups in the dialogue, but it also resulted in the participation of the newly formed Women's Coalition and a left wing Labour grouping, which further broadened the range of political perspectives around the table.

The multi-party negotiations reached a conclusion on 10 April 1998 when the text of what became known as the Belfast (after the location of the negotiations) or the Good Friday (after the date on which the agreement was concluded) Agreement (hereinafter: Agreement) was signed by the British and Irish governments and the ten political parties. The Agreement was then put to a popular vote in a referendum in both Northern Ireland and the Republic of Ireland in May 1998. The Agreement received the support of $94 \%$ of voters in the Republic and $71 \%$ in Northern Ireland.

While Catholics in both areas were heavily in favor of the Agreement, only an estimated $53 \%$ of Protestants in Northern Ireland supported it. This equivocal support from the Protestant community was, first, partially due to unease over the participation of Sinn Féin, which was perceived as a front for a "terrorist" organization, and, second, partially due to a fear of being "betrayed" by the British government; and, third, partially because the Agreement had been written with a considerable degree of ambiguity that enabled Sinn Féin to present it as a triumph for their views, thus feeding into Protestant suspicions and sense of mistrust. It was only due to a very strong campaign to encourage support for the Agreement and the personal intervention of the British Prime Minister Tony Blair that a slim majority of Protestants eventually voted in favor.

The third and final piece of this initial stage of the peace process was an election to the proposed Northern Ireland Legislative Assembly. This took place in June 1998 and paved the way for the establishment of a local parliament and a devolved power-sharing government for Northern Ireland.

\section{Key Elements of the Agreement}

The Agreement outlined the key constitutional and institutional proposals for Northern Ireland and its relations with both the rest of the United Kingdom and with the Republic of Ireland. It changed the Constitution of the Irish Republic to remove the existing claim to authority over the entire island of Ireland, and acknowledged that Northern Ireland would remain a part of the United Kingdom as long as the majority of the population so wished it. The Agreement also recognized that most Catholics considered themselves to be Irish rather than British and thus enabled all those born in Northern Ireland to claim either British or Irish nationality or both as a right. While many argued that the constitutional changes guaranteed the status of Northern Ireland within the UK, many Protestants saw this as still leaving the option open for Northern Ireland to become part of a united Ireland in the future. 
The Agreement provided for a devolved Assembly of 108 members to legislate and govern Northern Ireland. This was proportionately far more than similar devolved assemblies in Scotland and Wales but was designed to ensure that there would be broad representation of political views. It would also provide for an executive based on consociational principles, whereby the larger parties had a right to be part of the executive and to hold ministerial positions. This meant that the government would be an enforced coalition of the four or five larger parties rather than any form of majority rule or a voluntary coalition. The format of the consociational executive meant that there was no allowance for a formal opposition. ${ }^{12}$ The Agreement also included the creation of both cross-border (north-south) bodies involving the Northern Irish and Irish governments and other bodies that would interconnect the structures of government between Britain and Ireland.

In addition to the new institutions of governance, the Agreement provided for the creation of a Human Rights Commission and brought a number of existing anti-discrimination bodies together in a single Equality Commission. Both bodies were to be underpinned by new legislation, and the Human Rights Commission was required to bring forward proposals for a separate Bill of Rights for Northern Ireland that would reflect the particular circumstances of the region. The Agreement also included a number of actions to address two of the key elements of peace building: security sector reform (SSR) and the demilitarization of paramilitary groups. The Agreement set out the terms of reference for an international body to develop recommendations for policing reform and another to review the wider criminal justice system. It also committed the British government to removing the British Army from its enhanced security role and the removal of Northern Ireland's specific emergency legislation. The approach to dealing with the paramilitary groups was less comprehensive than disarmament, demobilization and reintegration (DDR) processes are generally envisioned since the Agreement only provided for, on the one hand, the release of all paramilitary prisoners by the state and, on the other hand, a commitment by the political representatives of the armed groups to decommission their weapons. The Agreement was thus broadly in line with the thinking emerging through the UN process that was subsequently consolidated in the Brahimi Report. This included the focus on engagement with local parties, moves to hold elections to establish a local government, reform of the security and justice sector, highlighting the importance of human rights and equality provisions in the new institutional structures and a commitment to the disarmament of the various paramilitary groups.

\section{Phase Two: Implementing the Agreement and Building the Peace}

I have already noted that the Agreement was supported by a majority of the population of Northern Ireland in the referendum in May 1998. However, there were significant dissenting voices. While Catholics voted overwhelmingly in favor of the Agreement, some within the Republican community felt it involved too much of a compromise with the British government, and they continued to assert their demand for a united Irish republic through the use of

12 Rupert Taylor, Consociational Theory: McGarry and O'Leary and the Northern Ireland Conflict (Abingdon: Routledge, 2009). 
"armed struggle." Their campaign of violence has continued, albeit at a much reduced level. Many within the Protestant community were, in turn, ambivalent about the Agreement. They welcomed the ending of the IRA violence and the changes to the Irish Constitution, but they felt that the British government was too lenient toward Sinn Féin and that it should have pursued the military campaign against the IRA. They also resented the proposals to reform the police, which they considered to have sacrificed much over the course of the conflict, objected to the release of any prisoners (including those involved in Loyalist paramilitary groups) and opposed Sinn Féin's inclusion in a power-sharing government because of its links with the IRA, which consistently refused to give up its weapons. And, while the British government and many from civil society argued that the Agreement confirmed Northern Ireland's status within the United Kingdom for the foreseeable future, many Protestants saw the Agreement as ultimately being a temporary measure that offered too many concessions to the Catholic and Irish constituency and left open the possibility of a united Ireland in the foreseeable future.

Following the elections in June 1998, the Ulster Unionist Party, the larger of the two main Protestant political parties, supported the implementation of the Agreement. But the smaller Democratic Unionist Party (DUP) refused to participate in the Executive because of the IRA's refusal to comply with the requirement to decommission its weapons. As a result, the Assembly was formally suspended for much of the period between 2000 and 2007, and Northern Ireland was governed by direct rule of the British government, as it had been between 1971 and 1998. Thus, from one perspective, this was a period of political crisis and uncertainty for the peace process. From another perspective, this was a period of sustained progress in peace building. This apparent contradiction existed because peace building is always a complex and multidimensional process, or at least successful peace building always needs to occur on multiple levels and involve multiple actors. The ongoing tensions and crises in the Northern Ireland peace process were largely a crisis in the elite-level political process. In contrast, many of the wider institutional reforms continued with the support of the British and Irish governments, and work done on the ground by civil society organizations flourished at this time. In fact, much of this work provided the foundations for the successful re-establishment of the devolved political institutions in 2007.

Much of the Agreement's implementation was the responsibility of the British and Irish governments rather than the local Assembly. The British government established the Human Rights Commission and the Equality Commission and passed the Human Rights Act in 1998. The latter incorporated the rights included in the European Convention on Human Rights into UK legislation and made a remedy for breach of a Convention right available in UK courts without the need to go to the European Court of Human Rights. The Irish government, in turn, passed legislation amending Articles 2 and 3 of the Irish Constitution, which related to claims of sovereignty over Northern Ireland. The British government also began the process for the release of paramilitary prisoners, which was completed by June 2000. It also began the process of reducing the role of the British Army in Northern Ireland and the removal of the military 
infrastructure. However, the most significant action was related to the reform of policing, which had long been a controversial issue in Northern Ireland. ${ }^{13}$

The Agreement provided for the formation of an international panel to develop proposals for a thorough reform of all aspects of policing. The Independent Commission on Policing for Northern Ireland was established in June 1998 under the chairmanship of Chris Patten, a former British Conservative Party minister. Its report, published in September 1999, is widely considered to have produced a model blueprint for a modern police organization. ${ }^{14}$ The report provided for a new body to be called the Police Service of Northern Ireland (PSNI) to replace the Royal Ulster Constabulary (RUC). The PSNI was to be structured around three core elements: a culture of human rights running through all aspects of police work and training; an extensive process of public accountability to a number of external independent bodies; and a commitment to working closely with wider society under the concept of "policing with the community," which was described as recognizing that policing was too important to be left to the police alone. The report also addressed the scale, representativeness and symbols of the new organization, all issues that were vitally important in Northern Ireland if the new organization was to achieve widespread public acceptance and legitimacy.

The Patten Report was accepted by the British government, which agreed to implement all 175 recommendations. The report received a diverse response from the political parties, with the general view being cautious. The Unionist parties were broadly opposed to any changes to policing, while Nationalist parties had wanted a more radical transformation than that outlined in the report. Eventually, most parties agreed to support the proposals and to participate in the oversight bodies designed to build public accountability. The exception was Sinn Féin, which was cautious in its response and refused to endorse the proposals. The party had wanted a complete break between the old RUC and the new PSNI, rather than a transition that involved existing police officers retaining for their posts while the organizational change took place around them. After a period of public debate, the police reform process began and the RUC was formally transformed into the PSNI in November 2001.

The political and institutional changes were complemented by an extensive range of activities involving a diverse array of civil society organizations to help build the peace on the ground. From one perspective, this work had begun as soon as the ceasefires had been declared, but, in reality, it was an extension of work that had been ongoing throughout the conflict among community and voluntary groups through dialogue, advocacy and the provision of services. This work was able to expand because of the change in the political and security context and the funding being provided by the European Union under its Peace Programme. The initial Peace Programme allocated $€ 667$ million over a four-year period to support peace building directly and indirectly. This included infrastructural, regeneration and employment initiatives as well as training, capacity building, education, dialogue, mediation and community development projects with a wide range of grass roots organizations.

13 See Graham Ellison and Jim Smyth, The Crowned Harp: Policing Northern Ireland (London: Pluto Press, 2000).

14 Patten Report, A New Beginning: Policing in Northern Ireland (Belfast: Independent Commission on Policing for Northern Ireland, 1999). 
The early availability of peace funding enabled the delivery of a diverse array of quickimpact projects that were designed to illustrate the benefits of peace and build support for the wider process. It has continued as a vital part of the overall transition process. European Union funding, along with funding from the USA and from the British and Irish governments, has continued to support a wide range of peacebuilding activities over the past twenty years. ${ }^{15}$ The grass roots peacebuilding work involved a wide range of civil society actors in its activities, including community workers, trade unions, churches and faith-based groups, former paramilitary prisoners, women's groups, youth workers, victims of the conflict and others. Much of this work has focused on the "softer" end of peacebuilding work, including building relationships and establishing trust between both individuals and communities, as well as between members of former armed groups. It also involved building relations and trust between communities and government agencies and state organizations. The work was understood within Robert Putnam's conceptualization of social capital that highlighted the value of bonding social capital within a distinctive ethic or residential group, bridging capital involving building links with distinct or opposing communities and also between individuals and communities and the institutions of state and authority. ${ }^{16}$ An example of one sustained area of work that highlights some of the work that was done and the impact it has had in the process of building the peace is discussed below.

I noted earlier that while the armed groups had ended their military campaign in 1994, Northern Ireland continued to be beset by inter-communal tensions and public disorder associated with the residential segregation that marked many working class communities and the annual cycle of commemorative parades. ${ }^{17}$ In July 1996, Northern Ireland experienced a week of rioting across the country. Many community workers in Belfast felt powerless to have any impact beyond reacting to the needs of victims in the aftermath of violent attacks. However, in the months that followed, they began to build local networks that linked people within and between communities through the use of the then newly emerging mobile phone technology. The mobile phones enabled community workers to monitor tense situations and flashpoints on the streets throughout the summer of 1997 while always remaining in contact with each other. This meant that they were better able to respond in real time to counter rumors, disperse crowds and intervene if violence began to occur, as well as to co-ordinate responses in neighboring segregated communities and to liaise with the relevant authorities. One of the key agencies in this regard was the police, whose interventions or even presence on the streets could serve to escalate tensions and provoke acts of violence. At this stage, before the police reform process had begun, few people had much trust in the police, although some recognized the pragmatic necessity of trying to engage with them to reduce the potential for violence. Over a long summer of responding to rioting and disorder, the seeds of trust began to take root between Protestants and Catholics and between community activists and the police.

15 Kenneth Bush and Kenneth Houston, The Story of Peace: Learning from EU PEACE Funding in Northern Ireland and the Border Region (Derry: University of Ulster, 2011).

16 Robert Putnam, Bowling Alone: The Collapse and Revival of American Community (New York: Simon and Schuster, 2000).

17 Neil Jarman, Material Conflicts: Parades and Visual Displays in Northern Ireland (Oxford: Berg, 1997). 
This emergent network was sustained through the winter and re-energized as tensions arose once again in the spring and summer of 1998. The new model of "mobile phone networks" to monitor and respond to tensions was disseminated through diverse networks in Belfast and other towns across Northern Ireland, and it soon became a ubiquitous part of peacebuilding activity. ${ }^{18}$ This was not an instant success, however. The mobile phone networks helped people to be able to reduce tensions and prevent rioting, but they were not always effective. They helped begin the process of building trust, but relationships sometimes broke down due to a variety of factors. Sometimes this was due to local disputes and sometimes due to events in the wider political sphere that were beyond local control. Initially such breakdowns in trust were quite serious and required time and energy to rebuild, but gradually the relationships became stronger and were able to withstand temporary stresses and strains. Over a number of summers these tensions were reduced, trust was consolidated and outbreaks of violence were less common.

Although the mobile phone networks largely involved activists from Protestant and Catholic communities, these activists also increasingly demanded contact with the police. The police reform program had begun in 2001, but, at that stage, Sinn Féin did not formally support the process, and therefore party members and many people in Catholic communities did not engage with the police. However, a common interest in helping to prevent rioting increasingly led to dialogue between Sinn Féin supporters and the police in working-class areas of Belfast. Initially this was done discretely and was publically deniable, but, over time, contact, particularly contact involving Sinn Féin political representatives, became more open and routine. This, in turn, helped provide the foundation for Sinn Féin to formally recognize the changes that had taken place in the transition from the RUC to the PSNI. This had become one of the key issues to be addressed before the devolved power-sharing government could be restored.

\section{Phase Three: Devolution and Stagnation}

While the peacebuilding work on the ground continued, attempts were being made to restore the local Assembly and re-establish the power-sharing Executive. This involved a number of distinct activities. The first significant move was when the IRA announced an end to its armed campaign and then formally decommissioned its weapons under the oversight of members of the Independent Monitoring Commission in September 2005. Secondly, Sinn Féin agreed to accept the legitimacy of the police reform process, and, in response, the DUP agreed to participate in a renewed power-sharing Executive with Sinn Féin. This was set out in the St Andrews Agreement of 2006, and new elections were then held in May 2007. The final stage of

18 See Neil Jarman, "Managing Conflict by Phone: The Mobile Phone Networks in Northern Ireland," in People Building Peace II: Successful Stories of Civil Society, ed. Paul van Tongeren et al. (Boulder, Colo.: Lynne Rienner Publishers, 2005), 435-40; Neil Jarman, "Vigilantism, Policing and Transition: Informal Justice in Northern Ireland," in Global Vigilantes: Anthropological Perspectives on Justice and Violence, ed. David Pratten et al. (London: Hurst, 2007), 319-48; Neil Jarman, "Managing Violence and Building Peace from Below," in Democracy in Crisis: The Dynamics of Civil Protest and Civil Resistance, Peace Report 2012, ed. Bert Preiss et al. (Vienna; Berlin: Lit-Verlag, 2013), 263-83. 
devolution occurred three years later following further negotiations that led to the Hillsborough Agreement in 2010 and that provided for the devolution of policing and justice to a minister in the Stormont Assembly.

On one level, this marked a new phase in the peace process with an inclusive power-sharing government in place since May 2007. In practice, the devolved government has struggled to achieve any degree of coherence; the Unionist and Nationalist parties have not been willing to work together very effectively; identity politics has continued to dominate debate, which has led to frequent stalemates over policy and political processes; and frequent crises have threatened the continuation of the Executive (similar challenges have been experienced in other consociational governments in countries coming out of conflict, for example, in Bosnia and Lebanon)..${ }^{19}$ Only recurrent interventions by the British and Irish governments ensured that the Assembly has not collapsed on a number of occasions.

Having a fragile government has been better than having no local government at all, but the constant crises and the lack of effective decision making has also helped to undermine confidence in the Agreement, the new institutions and the political parties. For example, the percentage of people voting in the Assembly elections declined by $15 \%$ between 1998 and 2011, and barely $55 \%$ of those eligible to vote did so in the 2016 Assembly elections.

The lack of a strong and coherent political leadership has also led to a sense of drift in consolidating the peace. One of the newly restored devolved government's first acts in 2007 was to abandon the existing strategy relating to peacebuilding work with the promise that it would introduce a new policy of its own to replace it. It took three years to produce a draft policy for consultation, and the new text was widely criticized as lacking substance and detail. It took a further two years to produce a revised version, which many civil society organizations felt was only marginally better as it still lacked a sufficiently broad strategic overview and failed to offer a clear vision for the future or a roadmap for how its goals would be achieved. This has meant that much of the peacebuilding work on the ground has been undertaken in the absence of any clear framework or longer-term strategy, and this has also occurred at a time when much of the funding for grass roots work is coming to an end. Although there has been no resurgence of paramilitary violence, the period has witnessed a decrease in public confidence and a decline in relations between the Protestant and Catholic communities on the ground. It has also seen the resurgence of street protests and inter-communal disorder from December 2012 through to late spring 2013, which was associated with a decision by Belfast City Council to fly the British Union Flag less frequently than previously. ${ }^{20}$ The protests have had a sustained impact on community and political relations, on relations between working class Protestant communities and the police and on general public confidence on the political institutions.

19 See Sumantra Bose, Bosnia After Dayton: Nationalist Partition and International Intervention (New York; Oxford: Oxford University Press, 2002) and Amal Hamdan, "The Limits of Corporate Consociation: Taif and the Crisis of Power Sharing in Lebanon since 2005," in Lebanon After the Cedar Revolution, ed. Are Knudsen et al. (London: Hurst, 2012), 39-59.

$20 \quad$ Neil Jarman and Geraldine Scullion, "Protecting Rights or Limiting Disorder? Freedom of Assembly and the Right to Protest," Shared Space 15 (2013): 5-16; Paul Nolan et al., The Flag Dispute: Anatomy of a Protest (Belfast: Queen's University, 2014). 


\section{Discussion: Progress Made and Challenges to be Faced}

More than twenty years since the paramilitary ceasefires of 1994, Northern Ireland has achieved a degree of stability. Many of the key elements of a peacebuilding strategy identified by the Brahimi Report have been implemented to some extent. Local actors have been centrally involved in the work of peace building, elections are generally free and fair, policing and justice has been reformed, a culture of human rights and equality underpins public institutions and the main paramilitary groups have disarmed. For many people these developments, along with the reduction in inter-communal tensions, riots and incidents of public disorder, are the new normal. Peace has been achieved.

Such views, however, often fail to acknowledge the relative fragility of the peace and the amount of work that continues to be done to make sure that nothing happens to disrupt the relative peace. Groups and individuals continue to undertake activities that are designed to build relations, increase trust and promote mutual understanding, manage tensions and mediate disputes.

Northern Ireland remains a highly segregated society, with contrasting and competing collective identities and with little in the way of shared symbols, shared history or a shared vision for the future. It is true that the military and paramilitary violence that dominated the 1970s, 1980s and early 1990s has largely ended, and for many that is the key success. To return to Johan Galtung's concept of a negative peace, many appear to be content with a level of negative peace, where the absence of routine acts of violence has provided sufficient security to live a normal life. Many of the political elites appear to have accepted a negative peace as an adequate foundation for future stability. And while the absence of violence is undoubtedly evidence of major progress and substantial improvements that have occurred to the infrastructure and physical environment in many urban areas, it is arguable that significant work still remains to be undertaken if the peace is to be sustainable in the longer term.

Approaches to conflict transformation have argued that, to build a sustainable peace in a divided society, it is important not just to end the violence, but to acknowledge and address the core structural issues that underpinned the conflict in the first place. Unless this is done, there is a risk that the conflict will re-emerge at a later stage. Historically, violent uprisings of various scale and intensity occurred in Ireland in $1798,1803,1848$, the 1870 s and 1916, before much of Ireland was given independence from the United Kingdom in 1921. Northern Ireland was born out of violent conflict and was governed for $5^{\circ}$ years, in part at least, through emergency legislation and conscious discrimination before sustained armed conflict erupted.

This conflict continued for more than a generation. Much work has been done to address some of the immediate causes of the violence through, for example, the introduction of equality and human rights legislation and the creation of a local Assembly with a powersharing Executive. But the new power structures have struggled to agree on the ways and means to effectively address the wider legacy of the conflict, including the impact of the conflict on victims and survivors. Arguments over the value of a truth commission, of continuing criminal investigations or of offering amnesties for past acts continue. And while considerable security sector reform has been completed, there has been less focus on addressing the legacy of irregular 
armed groups. The British Army is no longer seen on the streets, military infrastructure has been removed and the reform of policing is widely regarded as a model to be aspired to in many other places. But many of the paramilitary organizations continue to exist, and they retain a power base through a mixture of threat and admiration in many working class communities. In some areas they are still called upon to dispense forms of rough justice, and they are also deeply involved in forms of criminal activity. ${ }^{21}$

Northern Ireland also remains extremely divided and highly segregated. Working-class residential areas in Belfast and other urban areas are almost all segregated - Protestants live with other Protestants, and Catholics live with other Catholics. The education system remains heavily segregated, only $7 \%$ of pupils attend mixed or integrated schools. Thus, the vast majority of children are taught with the ethnic peers. The scale of segregation in housing and education, plus similar divisions in sport and socializing, helps ensure that the patterns of division remain and are continually being reproduced. These divisions, in turn, help to ensure that identity politics remain prominent, and, while the 1998 Agreement allowed everyone born in Northern Ireland to hold both British and Irish citizenship, most Protestants still consider themselves British, and most Catholics regard themselves as Irish. And although a growing number of young people describe themselves as "Northern Irish" rather than British or Irish, this remains a minority identity and one with limited emotional cache — at best it is still a secondary identity. The ethnic polarization within Northern Ireland, which extends through the political system and power structures of government, has been described as a form of "benign apartheid" in so far as it has been voluntarily adopted by many, albeit aided and abetted by systems of patronage and favor, which suits the political elite on both sides. Thus while considerable progress has been made in moving beyond conflict, and the Northern Ireland peace process is seen by many as a positive example of successful peace building, it has been limited in its scope and impact. The focus has been on establishing new institutions of governance and ensuring that the representatives of the divided communities are able to work together rather than anything more radical. It remains more of an example of conflict management or of conflict resolution rather than one of conflict transformation.

\section{Conclusions}

Northern Ireland has been touted as a recent example of successful peacebuilding, and indeed many aspects of the process over the past twenty years can be cited as a model for other societies emerging from conflict, albeit, as noted above, it remains a work in progress. The transition's key elements have in many ways validated the recommendations of both the UN's Agenda for Peace and Brahimi Reports, but they have also highlighted the narrowness of both reports. The Northern Ireland transition has highlighted the importance and value of a very broad inclusive process and the need for a long-term perspective for successful peacebuilding.

As well as having a broad array of local political, community and paramilitary actors involved in forms of dialogue and delivery, the process has relied heavily on the participation

21 Liam Kennedy, Who Was Responsible for the Troubles? Essays on the Northern Ireland Conflict (Dublin: Merrion Press, forthcoming). 
of the two national governments, which has served not only to help sustain the peace at critical times but has also helped to develop and deepen trust and confidence between the two national institutions. Beyond this, the process has highlighted the role that a wider network of international actors can play in peacebuilding. In the case of Northern Ireland, this has included the involvement of the US government as a chair for key talks or a host for important visits and meetings; the European Union providing substantial and sustained funding over a twenty-year period; the capacity of individual eminent persons to act as verifiers and objective chairs of bodies and institutions; and the willingness of participants in other peace processes to offer advice, support and guidance. All of these factors highlight the complexity of peacebuilding practice and the need for a consistent commitment by diverse actors to enable a society to make the transition from persistent conflict to sustainable peace.

\section{Bibliography}

Borer, Tristan Anne, John Darby, and Siobhán McEvoy-Levy. Peacebuilding After Peace Accords: The Challenges of Violence, Truth and Youth. Notre Dame, Ind.: University of Notre Dame Press, 2006.

Bose, Sumantra. Bosnia After Dayton: Nationalist Partition and International Intervention. New York; Oxford: Oxford University Press, 2002.

Boutros-Ghali, Boutros. An Agenda for Peace. New York, United Nations, 1992. (Available at: http://www.un-documents.net/a47-277.htm. Accessed May 25, 2016.)

Brahimi Report. Report of the Panel on United Nations Peace Operations. New York, United Nations, 200o. (Available at: http://www.un.org/en/ga/search/view_doc.asp?symbol=A/55/305. Accessed May 25, 2016.)

Brewer, John. Peace Processes: A Sociological Approach. Cambridge: Polity Press, 2010.

Bush, Kenneth, and Kenneth Houston. The Story of Peace: Learning from EU PEACE Funding in Northern Ireland and the Border Region. Derry: University of Ulster, 2011.

Collier, Paul. Wars, Guns and Votes: Democracy in Dangerous Places. London: Vintage Books, 2010.

Darby, John, ed. Violence and Reconstruction. Notre Dame, Ind.: University of Notre Dame Press, 2006.

Ellison, Graham, and Jim Smyth. The Crowned Harp: Policing Northern Ireland. London: Pluto Press, 2000.

Galtung, Johan. Theories of Peace: A Synthetic Approach to Peace Thinking. Oslo: International Peace Research Institute, 1967.

Hamdan, Amal. "The Limits of Corporate Consociation: Taif and the Crisis of Power Sharing in Lebanon since 2005." In Lebanon After the Cedar Revolution, edited by Are Knudsen and Michael Kerr, 39-59. London: Hurst, 2012.

Jarman, Neil. Material Conflicts: Parades and Visual Displays in Northern Ireland. Oxford: Berg, 1997.

Jarman, Neil. "Managing Conflict by Phone: The Mobile Phone Networks in Northern Ireland." In People Building Peace II: Successful Stories of Civil Society, edited by Paul van Tongeren, 
Malin Brenk, Marte Hellema and Juliette Verhoeven, 435-40. Boulder, Colo.: Lynne Rienner Publishers, 2005.

Jarman, Neil. "Vigilantism, Policing and Transition: Informal Justice in Northern Ireland." In Global Vigilantes: Anthropological Perspectives on Justice and Violence, edited by David Pratten and Atreyee Sen. London: Hurst, 2007.

Jarman, Neil. "Managing Violence and Building Peace from Below." In Democracy in Crisis: The Dynamics of Civil Protest and Civil Resistance, Peace Report 2012, edited by Bert Preiss and Claudia Brunner, 263-83. Vienna; Berlin: Lit-Verlag, 2013.

Jarman, Neil, and Geraldine Scullion. "Protecting Rights or Limiting Disorder? Freedom of Assembly and the Right to Protest." Shared Space 15 (2013): 5-16.

Kennedy. Liam. Who Was Responsible for the Troubles? Essays on the Northern Ireland Conflict. Dublin: Merrion Press, forthcoming.

Lederach, John-Paul. Building Peace: Sustainable Reconciliation in Divided Societies. Washington: United States Institute of Peace, 1997.

Miall, Hugh, Oliver Ramsbotham, and Tom Woodhouse. Contemporary Conflict Resolution. Cambridge: Polity Press, 2001.

Nolan, Paul, Dominic Bryan, Claire Dwyer, Katy Hayward, Katy Radford, and Peter Shirlow. The Flag Dispute: Anatomy of a Protest. Belfast: Queen's University, 2014.

Patten Report. A New Beginning: Policing in Northern Ireland. Belfast: Independent Commission on Policing for Northern Ireland, 1999.

Putnam, Robert. Bowling Alone: The Collapse and Revival of American Community. New York: Simon and Schuster, 200o.

Taylor, Rupert. Consociational Theory: McGarry and O'Leary and the Northern Ireland Conflict. Abingdon: Routledge, 2009.

\section{(2)}

Neil Jarman is a Research Fellow at the Senator George J. Mitchell Institute for Global Peace, Security and Justice at Queen's University, Belfast, and is the director of the Institute for Conflict Research, a Belfast-based not-for-profit organization. He has worked extensively on issues associated with the political transition in Northern Ireland, including inter-communal violence, police reform, hate crimes, immigration and migration, as well as general human rights and equality issues. Much of his work is focused on the importance of dialogue and relationship building as part of the process of peacebuilding and on the role civil society organizations play in conflict transformation. 